\title{
STUDENTS' PROBLEMS FACE IN ONLINE LEARNING AMIDT PANDEMIC COVID-19
}

\author{
Joko Prayudha. $\mathrm{S}^{1}$ \\ ${ }^{1}$ Universitas Bengkulu \\ Email: jokoprayudha@gmail.com
}

\begin{abstract}
The existence of the corona virus requires face-to-face teaching to be replaced with online teaching. As a new alternative in learning, it will certainly bring up several obstacles that will be faced by students while studying. This study aims to determine the difficulties faced by students during online learning by using various applications that support online learning such as Whats App, Google Classroom and Zoom Meeting. In this study, qualitative methods have been used and a descriptive approach was used to explain the data. In data collection, questionnaires and interviews were used to obtain in-depth information about the difficulties faced by students during online learning. The results in this study indicate that students experience various kinds of obstacles in the implementation of online learning, such as (1) operating learning applications, (2) limited internet quota, (3), incomplete learning resources / materials, (4) poor communication, and (5) decreased learning motivation during online learning, however, even though there were obstacles faced by the students, it did not stop them from continuing to study in difficult times such as the COVID-19 pandemic.
\end{abstract}

Keywords: Students' Problem, Online Learning, COVID-19

This work is licensed under Creative Commons Attribution License 4.0 CC-BY International license

\section{INTRODUCTION}

In 2020 the world was shocked by the phenomenon of the spread of a dangerous virus, namely the corona virus or abbreviated as COVID-19. This virus caused panic around the world and stopped many activities, including in the world of education. Rajab (2020) argues that the presence of the corona virus has an effect on the education sector. The government must temporarily close schools, universities and all public places to avoid COVID-19 (Bhamani et al, 2020). All schools in the world announce the expectations of teachers, schools must close their doors (Nasr, 2020). So that with the closure and termination of face-to-face activities at school, it is hoped that it will stop the spread of the corona virus. However, the closure of schools does not mean that teaching and learning must also stop. Teachers and all educators are required to change their teaching methods in school 
management and the government has designed face-to-face learning to an online learning mode because of COVID-19. This recommendation is in accordance with the regulations provided by the Ministry of Education and Culture, this policy leads the education sector to close schools that are suitable for students studying from home.

With the changed of face-to-face learning to virtual learning, it requires teachers and students to be able to master online learning technology. Normal classroom teaching cannot be carried out and the COVID-19 pandemic has shaken all school systems (Jhonson, Veletsianos and Seaman, 2020). Online learning has become the best alternative in the midst of the COVID-19 pandemic like this to prevent the spread of the COVID-19 virus. So that both teachers and students must be able to use various learning applications to continue learning. Reimers (2020) states that online learning is a very supportive medium in conquering the problems of the world of education during the COVID-19 pandemic. So, to continue learning, online learning is the best alternative choice in the COVID-19 pandemic situation. Changes in system learning force the system schools must implement distance education or online learning (Rasmitadila et al, 2020). So, it can be summarized that online learning in the midst of a pandemic is very important. Technology has evolved and offers many tools to help teachers teach online classrooms (Wilson, 2018). Hartono (2012) states that the use of information and communication technology in learning can help teachers or students. The use of this technology can be a new way to continue learning to students in the midst of the COVID-19 pandemic so that learning continues.

Then Ali (2020) said that the technology is of particular concern, especially in the COVID-19 pandemic situation. The education system needs to collaborate with technology in education and increase students' awareness of its application in learning (Al-Takhyneh, 2018). With adequate technology support, online learning will run well so that students and teachers can still learn even through the internet. In the context of language learning, the internet provides students with access to automatic documents and resources useful for their language acquisition (Zamari et al, 2012). Therefore, both teachers and students must understand the use of technology, especially learning technology or learning applications so that learning can run well. Teach Thought (2020) explains that the use of applications in learning will continue the learning experience in human life. It means that, in the midst of a viral pandemic like this, online teaching will help teachers and students to provide a learning experience that is different from previous teaching. If online learning is carried out until the end of the year, it will be a challenge for teachers and students. This means that online learning will provide new ways for each student to learn and will provide new perspectives in the learning process. 
Online learning also marks new generations of learning as "your pocket" and "on the fly" (Hutchinson et. Al., 2008). It means that the use of technology provides services to students to reach learning that does not necessarily require coming to school. Only by using technology devices can students get learning with their teachers so that learning continuity will not stop because of the COVID-19 pandemic. A large number of studies also support the positive results of online learning. Thus, the existence of online learning is able to facilitate students to continue to connect with their teachers in teaching and learning activities.

However, with the existence of a new learning system like this, it will certainly bring up various kinds of obstacles that will be faced by both teachers and students in the implementation of online learning. With this online teaching method, it will provide a new atmosphere and challenges for both students and teachers in implementing online learning. This challenge is for those who are not used to using these applications in learning so that students' interest in learning decreases. Saputra (2015) states that there are factors that can affect the course of learning, namely internal factors and external factors. These factors are factors that come from students themselves, such as laziness, boredom, staff and so on, while external factors are caused by conditions outside of the students themselves such as school conditions, learning environment, teaching methods, teacher-student and student-student relationships and so on. The online learning environment must be different from face-to-face learning, causing problems that occur to students. There are many factors that must be considered by teachers and students during online learning programs (Berry, 2019). Advances in technology, connection speed and availability of tools will also help students improve online collaboration (Robinson, Kilgore and warren, 2017). Students should use the internet effectively to develop themselves, because that is their obligation (Gultekin et al, 2020). So it is important to have good communication between teachers and students in order to establish good communication in online learning. Teachers must provide feedback in ways and amounts that students can learn most effectively while following up on their influence on their progress and skills with the subject (Canals and Robbins, 2017). Therefore, this study aims to determine: (1) The obstacles experienced by students during the implementation of online learning during the COVID-19 pandemic. (2) How the students solve the problems.

\section{METHOD}

This research used qualitative methods in its implementation. The types of research used was descriptive qualitative. Descriptive research is a type of research that describes a problem. Descriptive research aims to describe a population, situation or phenomenon accurately and systematically. This type of research can answer the what, where, when and 
how questions, but not why the questions (Mukhtar, 2013). Unlike in experimental research, the researcher does not control or manipulate any variables, but only observes and measures it.

The approach used was descriptive approach by collecting data, describing, analyzing and describing the data. Merriam (2009) states that in qualitative research, the researchers try to explain their experiences, their perceptions and express their opinions about the object being carried out. Sugiyono (2014) also adds that descriptive qualitative methods are used to see the condition of an object being studied naturally where the researcher is the key instrument in the process of implementing the research. Stake (2010) states that qualitative research is dependent on human perceptions of the subject and the time that has been used on a matter discussed.

In data collection, questionnaires and interviews have been used to obtain more indepth answers. The population in the study were all students at SMPN 13 Bengkulu City, while the sample used was all grade VII students. The number of students in this class was 30 students by distributing questionnaires via google form and interviews were conducted to selected students to explore students' perceptions about the problems they faced during online learning. After the data was collected, the next step was to analyse the data to get a conclusion. Then the data that has been collected will be described descriptively.

\section{FINDINGS AND DISCUSSION}

In this part present the result of questionnaire and interview result about the students problems face online learning activity during COVID-19.

Table 1. Questionnaire result

\begin{tabular}{|c|c|c|c|c|}
\hline \multirow{3}{*}{ NO } & \multirow{3}{*}{ Questions } & \multicolumn{2}{|c|}{ Answer } & \multirow{3}{*}{ Persentage } \\
\hline & & \multirow{3}{*}{$\begin{array}{r}\text { Yes } \\
28\end{array}$} & \multirow{3}{*}{$\begin{array}{c}\text { No } \\
2\end{array}$} & \\
\hline & & & & \\
\hline 1 & $\begin{array}{l}\text { Do you think that online learning gives you challenge } \\
\text { in learning activities? }\end{array}$ & & & $9,3 \%$ \\
\hline 2 & $\begin{array}{l}\text { Do you understand how to use the learning application } \\
\text { such as WhatsApp, Google Classroom and Zoom } \\
\text { Meeting? }\end{array}$ & 25 & 5 & $8,3 \%$ \\
\hline 3 & $\begin{array}{l}\text { Do you have trouble in use the online learning } \\
\text { application? }\end{array}$ & 22 & 8 & $7,3 \%$ \\
\hline 4 & Do you have an adequate internet connection, such as & 15 & 15 & $5 \%$ \\
\hline
\end{tabular}




\begin{tabular}{|c|c|c|c|c|}
\hline & having a private internet (WIFI) connection? & & & \\
\hline 5 & Does online learning drain a lot of internet quota? & 30 & 0 & $10 \%$ \\
\hline 6 & $\begin{array}{l}\text { Is the material presented during online learning easy } \\
\text { to understand? }\end{array}$ & 12 & 18 & $4,0 \%$ \\
\hline 7 & $\begin{array}{l}\text { Does online learning allow you to have two-way } \\
\text { communication with the teacher? }\end{array}$ & 17 & 13 & $5,6 \%$ \\
\hline 8 & $\begin{array}{l}\text { Does your teacher provide feedback when you ask } \\
\text { questions or discuss during online learning? }\end{array}$ & 20 & 10 & $6,6 \%$ \\
\hline 9 & Do you comfortable with online learning methods? & 12 & 18 & $4,0 \%$ \\
\hline 10 & $\begin{array}{l}\text { Does online learning make you motivated to continue } \\
\text { learning? }\end{array}$ & 7 & 23 & $2,3 \%$ \\
\hline
\end{tabular}

Online learning can indeed be a solution to the difficult situation like today, although it cannot be denied that there are many obstacles faced in the implementation (Windiarti et al., 2019). From the data displayed in the table above, it shows the results related to the problems students face when implementing online learning. For the first question related to online learning, 28 students said that online learning gave them challenges when learning online. This is because students are not accustomed to implementing online learning, and also there is no socialization or practice of using previous applications carried out by the school related to how to use online learning applications. However, two students said that they did not feel that online learning was a challenge. Then the second question was related to the use of learning applications such as WhatsApp, Google Classroom and Zoom Meeting, as many as 25 students said that they understood how to use and run the application as an online learning medium. Some students said that when online learning was first implemented, they felt very confused in running the application. However, over time the students understood how to use the learning application during online learning. There were five students who thought that they were still having trouble running the online learning application, such as running the Zoom Meeting application. Students find it difficult to run the features of the application.

For the third question related to difficulties when running the learning application, 22 students said that they sometimes experienced difficulties in using online learning applications, ranging from connection problems, wrong learning links and unsupervised class irregularities. Meanwhile, eight students said they did not experience significant difficulties when running the online learning application. The fourth question is about internet connection constraints, as many as 15 students said that they have a private internet 
connection (WIFI) at their home so they can access learning applications at any time without having to think about quotas. Meanwhile, as many as 15 students stated that they did not have private internet (WIFI) at home so they used regular internet quota when implementing online learning. The results of research conducted by Rahma, et. al (2021) shows the results that many students are not satisfied with the implementation of online learning, teachers are also less able to deliver learning material well, internet signals are unstable and expenditure of large quotas.

The fifth question was related to the use of quotas when learning online, as many as 30 students said that online learning drained a lot of quotas, especially in opening files that were large in size and some students said that online learning using video conferencing also drained a lot of quota, resulting in quite a lot of expenses. in online learning. Then the sixth question is related to the delivery of material provided by the teacher during the implementation of online learning, as many as 12 students said that the material provided by the teacher was easy to understand, but 18 students said that online learning made it difficult for students to understand the material provided by the teacher during learning. online takes place. Some students said that sometimes the material provided by the teacher was only basic material that was not too deep so that students felt that the material provided was just ordinary material and sometimes the teacher only provided material without explaining the material that had been given so this was a drawback when learning online. Many tasks with short deadlines are also an obstacle for students when implementing online learning (Kompas, 2020). Even though this is a problem for students, to overcome the problem of material obscurity, sometimes students seek explanations independently via the internet. The difficulties faced by students during online learning include less supportive internet signals, some students lacking quotas, many distractions when studying at home, the material provided by the teacher is less understandable and the teacher's lack of readiness in preparing the material (Gunadha \& Rahmayunita, 2020; Utami et al., 2020).

For the seventh question regarding two-way communication between students and teachers, 17 students said that online learning provides two-way access between teachers and students so that it provides space for students to provide questions, ideas and opinions when doing online learning through the comments or discussion fields available in online learning features. However, as many as 13 students said that online learning was difficult to provide two-way communication between teachers and students. So that it makes students sometimes feel confused when doing online learning. Then for the eighth question regarding feedback during the implementation of online learning between teachers and students. As many as 20 students said that during online learning and online discussions the teacher often gave replies 
or feedback to students as a response while learning. Meanwhile, as many as 10 students said that the teacher rarely provides feedback when learning online. Students give the opinion that sometimes teachers are not responsive to discussions or delivery of messages conveyed by students. The quality of education in tertiary institution can be seen from learning outcomes and assessed from students' perception of learning (Griffith, 2002). So that sometimes the opinions or ideas given are just left in the comment's column.

Then the ninth question about the comfort of students when learning online, as many as 12 students felt comfortable with the implementation of online learning. However, 18 students said that they did not feel comfortable with the online learning system. The main reasons for students regarding the inconvenience of online learning are the non-living learning atmosphere, lack of student creativity, not being focused, and not being able to play with classmates. Furthermore, the tenth question regarding student motivation towards online learning, as many as seven students felt that online learning made them motivated to continue learning. However, as many as 23 students felt uncomfortable with online learning and felt unmotivated to carry out online learning. Teachers play the most important role in implementing online learning because they are controllers in learning process (Bao, 2020). With the implementation of online learning, they stop doing activities at school, cannot be creative, even feel bored when doing online class learning.

In research conducted by Almaghas (2018) shown that students more comfortable choosing face-to-face learning than online learning. It means online learning make students have not interest and motivation in learning online activity. Online learning can also make students feel stressed, then online learning also makes students bored and lazy faster (Dhawan, 2020). Therefore, the teacher must be able to make the online learning atmosphere more attractive without having to give a lot of tasks so that it can minimize the risk of stress on students.

\section{CONCLUSIONS}

The implementation of online learning is a new way of learning in the midst of the COVID-19 pandemic. This is a new challenge for both the government, teachers and students themselves so that the teaching and learning process can continue. With this new method, various kinds of problems arise by students in the implementation of online learning. The conveniences of these problems are (1) the operation of learning applications, (2) limited internet quota, (3), incomplete learning resources / materials, (4) poor communication, and (5) decreased learning motivation during online learning. However, even though there are obstacles faced by students, it does not prevent them from continuing to study in difficult 
times such as the COVID-19 pandemic. Suggestion for further researchers is to be able to carry out research related to the effectiveness of online learning in learning English during COVID-19 pandemic. The results of this research can be used to provide an overview related to current learning, so that it can be used to expand the scope of this research.

\section{REFERENCES}

Ali, Wahab. (2020). Online and Remote Learning in Higher Education Institutes: A Necessity in Light of COVID-19 Pandemic. Higher Education Studies 10(3): 16. https://doi.org/10.5539/hes.v10n3p16.

Almaghaslah, D., Ghazwani, M., Alsayari, A., \& Khaled, A. (2018). Pharmacy Students' Perceptions Towards Online Learning In A Saudi Arabia Pharmacy School. Saudi Pharmaceutical Journal, 26(5), 617-621. https://doi.org/10.1016/j.jsps.2018.03.001.

Al-Takhyneh, Bahjat. (2018). Attitudes Towards Using Mobile Applications in Teaching Mathematics in Open Learning System. International Journal of E-Learning \& Distance Education, 33:16.

Bao, W. (2020). COVID-19 and Online Teaching In Higher Education: A Case Study of Peking University. Human Behavior and Emerging Technologies, 2(2), 113-115. https://doi.org/10.1002/hbe2.191.

Berry, Sharla. (2019). Teaching to Connect: Community Building Strategies for the Virtual Classroom. Online Learning, 23(1). https://doi.org/10.24059/olj.v23i1.1425.

Bhamani, Shelina, Areeba Zainab Makhdoom, Vardah Bharuchi, Nasreen Ali, sidra Kaleem, and Dawood Ahmed. (2020). Home Learning In Times of Covid: Experiences of Parents. Journal of Education and educational Development. 7(1):9. https://doi.org/10.22555/joeed.v7il.3260.

Canals, Laia, and Jackie Robbins. (2017). An Exploratory Studyof Feedback Practices for Written and Oral Tasks in an Online English Course. CALL in a Climate of Change: Adapting to Turbulent Global Conditis- Short Papers from EUROCALL 2017.

Dhawan, S. (2020). Online Learning: A Panacea in the Time of COVID-19 Crisis. Journal of Educational Technology $\quad$ System, $49(1), \quad$ 5-22. https://doi.org/10.1177/0047239520934018.

Griffith, J. (2002). Is Quality or Effectiveness An Emprically Demonstrable School Atrribute? Statistical Aids for Determining Appropriate Level of Analysis. School Effectiveness and School Improvement, 13(1), 91-122. https://doi.org/10.1076/sesi.13.1.91.3441. 
Gultekin, dkk. (2020). Investigation of Academic Staff's Self-Efficacy Using the Educational Internet. Higher Education Studies 10(3): 26. https://doi.org/10.5539/hes.v10n3p26.

Gunadha, R., \& Rahmayunita, H. (2020). Kuliah Online saat Corona Picu Ketimpangan Akses Bagi Mahasiswa Miskin. https://www.suara.com/news/.

Hartono. (2012). ICT, Information and Communication Technology in Language Learning Semarang: Pelita Insani.

Hutchinson, M., Tin, T., \& Cao, Y. (2008). "In-your-pocket” and "on-the-fly”. Meeting The Needs of Today's New Generation Of Online Learners with Mobile Learning Technology. AU Press.

Johnson, Nicole, George Veletsianos, and Jeff Seaman. (2020). US. Faculty and Administrators' Experience and Approach In the early Weeks of the COVID-19 Pandemic. Online Learning Journal, 24(2). https://doi.org/10.24059/olj.v24i2.2285

Kompas. (2020). Hambatan dan Solusi Belajar dari Rumah. https://muda.kompas.id/baca/2020/04/10/hambatan-dan-solusi-saat-belajar-daringdari-rumah/

Merriam, S., B. (2009). Qualitative Research: A Guide to Design and Implementation. San Francisco: Jossey Bass Willy Imprint.

Mukhtar. (2013). Metode Praktis Penelitian Deskriptif Kualitatif. Referensi: Jakarta.

Nasr, Nancy. (2020). Teachers as Students: Adapting to Online Methods of Instruction and Assessment in the age of COVID-19. Electronic Journal for Research In Science \& Mathematic Education, 4.

Rahma, Salma., Sinung Khoirot \& Nurjanah. (2021). Dampak Pembelajaran Jarak Jauh Pada Masa COVID-19 di SMK Muhammadiyah 1 Sukoharjo. Jurnal Pendidikan, 30(1), 53-58.

Rajab, M. (2020). Pendidikan di Tengah Pusaran Wabah Corona. https://news.com/kolom/d4945590/pendidikan-di-tengah-pusaran-wabah-corona

Rasmitadila, dkk. (2020). The Perception of Primary School Teachers of Online Learning During the COVID-19 Pandemiic Period: A Case Study In Indonesia. Journal of Ethnic and Cultural Studies, 7(2): 90. https://doi.org/10.29333/ejecs/388.

Reimers, F. (2020). Supporting the Continuation of Teaching and Learning During COVID19 Pandemic. OECD Journal.

Robinson, Heather A., Whitney Kilgore, and Scott J. Warren. (2017). Care, Communication, Support: Core for Designing Meaningful Online Collaborative Learning. Online Learning, 21(4). https://doi.org/10.24059/olj.v21i4.1240. 
Saputra, A. (2015). Faktor yang Mempengaruhi Kelancaran Pembelajjaran Pejasorkes Kelas $\begin{array}{lllll}V \text {-VI } & d i & S D N & \text { Kembangjitengan } & \text { Sleman. }\end{array}$ https://eprints.uny.ac.id/24252/1/SKRIPSI.Pdf.

Stake, R. E. (2010). Qualitative Research. The Giuilford Press.

Sugiyono. (2014). Memahami Penelitian Kualitatif. Bandung: Alfabeta.

Teach Thought. (2020). The Benefits of Blended Learning. Retrieved March, 12, 2021, from: https://teachthought.com/technology/the-benefits-of-blended-learning/.

Utami, S., Rufaidah, A., \& Nissa, A. (2020). Kontribusi Self-eficiacy Terhadap Stress Akademik Mahasiswa Selama Pandemi COVID-19 Periode April-Mei 2020. Teraputik Jurnal Bimbingan dan Konseling, 4(1), 8.

Wilson, Stefanie D. (2018). Leading Edge Online Classroom Education: Incorporating Best Practices Beyond Technology. American Journal of Business Education (AJBE) 11(3): 41-48. https://doi.org/10.19030/ajbe.v11i3.10187.

Windiarti, S., Fadilah, N., Dhermawati, E., \& Pratolo, B. W. (2019). Teachers'Perception Toward the Obstacles of E-learning Classes. Ethical Lingua Journal of Language Teaching and Literature, 6(2), 117-128. https://doi.org/10.30605/25409190.v6.117128.

Zamari, Z. M., Adnan, A.H. M., Idris, S. L., \& Yusof, J. (2012). Students' Perception of Using Online Language Leraning Materials. Procedia -Social and Behavioral Science, 67, 611-620. 